\title{
Interplay between medicine and biochemistry
}

Citation for published version (APA):

Hemker, H. C. (1986). Interplay between medicine and biochemistry. In R. F. A. Zwaal, \& H. C. Hemker (Eds.), Blood Coagulation (pp. 307-312). Elsevier Science. New Comprehensive Biochemistry Vol. 13 https://doi.org/10.1016/S0167-7306(08)60057-5

Document status and date:

Published: 01/01/1986

DOI:

10.1016/S0167-7306(08)60057-5

Document Version:

Publisher's PDF, also known as Version of record

\section{Please check the document version of this publication:}

- A submitted manuscript is the version of the article upon submission and before peer-review. There can be important differences between the submitted version and the official published version of record.

People interested in the research are advised to contact the author for the final version of the publication, or visit the DOI to the publisher's website.

- The final author version and the galley proof are versions of the publication after peer review.

- The final published version features the final layout of the paper including the volume, issue and page numbers.

Link to publication

\footnotetext{
General rights rights.

- You may freely distribute the URL identifying the publication in the public portal. please follow below link for the End User Agreement:

www.umlib.nl/taverne-license

Take down policy

If you believe that this document breaches copyright please contact us at:

repository@maastrichtuniversity.nl

providing details and we will investigate your claim.
}

Copyright and moral rights for the publications made accessible in the public portal are retained by the authors and/or other copyright owners and it is a condition of accessing publications that users recognise and abide by the legal requirements associated with these

- Users may download and print one copy of any publication from the public portal for the purpose of private study or research.

- You may not further distribute the material or use it for any profit-making activity or commercial gain

If the publication is distributed under the terms of Article $25 \mathrm{fa}$ of the Dutch Copyright Act, indicated by the "Taverne" license above, 


\section{Interplay between medicine and biochemistry}

\section{H. COENRAAD HEMKER}

\section{University of Limburg, Biomedical Centre, Maastricht (The Netherlands)}

Medical science, not surprisingly, flowers at the interface of medicine and science. Its bloom thus results from the confrontation of two different cultures. Although it is good custom to emphasize the warm relations between the two, it is of no use to dissimulate the distance that separates doctors and scientists. Indeed the gap is large enough to use the expression 'two cultures' not exclusively as a description of the situation between the sciences and the humanities. There is sufficient reason to maintain that it applies as well to the sciences confronting medicine. A good doctor is primarily interested in the well-being of his patients and uses scientific insight only as one of the tools of his trade. It is rare to find him develop an expert knowledge in a branch of natural science. On the other hand a scientist opts for insight, no matter how delighted he may be to find his results of use in the diagnosis and treatment of the sick. The fundamental difference in attitude between the two makes that the exploration of the interface between science and medicine often is difficult. In fact every symposium or congress in one field or another of human pathobiology teaches us that although doctors and scientists meet frequently, their views only amalgamate with difficulty.

There is good reason to stress this point if one is to discuss the interplay between medicine and science in the field of blood coagulation. There is hardly another subject of study in human biology where the clinics have remained the most important source of information for so long. Whereas e.g. endocrinology or immunology had their science components developed already during the first half of this century, haemostasis research remained the playground of the doctors. There probably are multiple reasons for this, such as the rareness of congenital bleeding disorders, that are the most natural first object of study or the complexity of the problem that presents itself already after the first few experiments, to defy any simplifying hypothesis etc. I would not maintain that blood coagulation per se is more complicated than immunology or endocrinology or any other subject of human pathophysiology. It only presents its complexity right at the beginning of the most simple experiments. This makes people tend to shy away from an attempt at a formal scientific approach. Even in 1962, when I planned to enter the field, my colleague biochemists were shocked to see that I would consider that kettle of fish worthy of my attention. My medical colleagues did not share these objections al- 
though they failed to see why I should stop medical practice, while playing around with tubes. At that time the lab carrying most weight in the field of blood coagulation was that in Oxford where R.G. Macfarlane, M.D. and clinical pathologist. together with Rosemary Biggs, Ph.D. and originally a botanist, formed a nucleus around which many medical doctors and several scientists gathered and formed a group that was responsible for many fine contributions. Yet, even there, the application of modern biochemical techniques was less fruitful than the typical coagulation approach, that in essence exists of measuring clotting times in endless permutations and combinations of mixtures. 'After all' Rosemary Biggs used to say 'After all it is more like cooking than like anything else'. In Detroit, Walter Seegers, M.D. and professor of physiology, devoted his life to attempts at purifying prothrombin and other clotting factors. Rereading the articles from this group one is struck by the tremendol's amount of work, hy the many observations done that can only be explained in the light of our newest knowledge (cf. Ch. 9B). Also by the fact that the results did not even allow the construction of a refutable set of hypotheses.

It must be said that, with all their cooking and curing the doctors had done a good job. By 1960 most of the coagulation 'factors' had been defined as functions lacking in haemophilic disorders. The role of blood platelets had been discerned and the pathology of thrombosis had been described in great detail. A good start had been made with anticoagulant treatment and with the treatment of haemophilia by the use of plasma fractions.

Mentioning the pathology of thrombosis automatically evokes Virchow and the scientists of the 19th and early 20th centuries. What about the interactions between medicine and science in those days? Buchanan (M.D.) was the first to report (1836) that catalytic amounts of clotted blood could coagulate a fibrinogen solution. His fibrinogen solution was prepared involuntarily in the scrotum of patients suffering from a hydrocele. These experiments can - a posteriori - hardly be thought to be conclusive but they did introduce the concept of coagulation by enzymatic conversion that we now know to be correct. In the second half of the 19 th century this concept was heavily opposed a.o. by Alexander Schmidt who favoured the idea that fibrin arises from a stoichiometric interaction between blood proteins. Others, like e.g. Hammersten sustained Buchanan's view, often with experimental evidence that up to this moment seems convincing. Nevertheless, even with all the old literature on one's desk it is hard to find out what was really meant. Some workers like Hammersten describe experiments with meticulous precision; others, like Schmidt prefer general considerations but in any case our observation of their results is tinged with our present knowledge. The controversy that dominates the blood coagulation literature in the latter half of the last century is that between those who seu fibrin as the product of the catalytic action of thrombin on fibrinogen and those who think fibrin to arise from the stoichiometric action of fibrinogen and a second substance. The gist of this controversy seems to be that at that time no distinction could be made between the functions of thrombin and that of thromboplastin. In trying to repeat the old experiments it often up to this day 
cannot be made clear in what modern terms they should be explained. The same confusion repeats itself about half a century later when the two functions of thromboplastin are recognised: tissue thromboplastin as we know it and 'bloodthromboplastin' now known to be prothrombinase. With combinations of crude blood fractions and thromboplastin-containing preparations (cells, serum etc.) observations can be made that indeed suggest stoichiometric interactions but others suggestive of enzymatic interaction are possible as well. Join to this that nomenclature in those days was confused to the degree of complete incomprehensibility and that communications often hardly crossed the national borders then one will be hardly surprised by the fact that a communis opinio was not reached until around the turn of the century. After 1876 Schmidt began to accept reluctantly that thrombin might play a role in the generation of fibrin and he postulated that it circulates in the blood in an inactive precursor state.

The type of argument used in the 19th century discussions switched from medical observations to chemical experiments and back with an astonishing ease, especially where, as in the case of Schmidt, the borderline between discussion and speculation faded. Schmidt was a medical doctor and professor of physiology. Hammersten was a chemist. It would in my opinion be unjustified to attribute the difference in style between these two scientist to a difference in discipline. I would rather see it as a question of temper. Temper anyhow spices these discussions, even to a degree that we nowadays would think unpalatable. From the literature of the 19 th century the impression remains that doctors and chemists did not work in different worlds but rather cooperated and penetrated each others fields freely. Outside coagulation one might think of the chemist Pasteur who cured rabies or, conversely, of the first generation of biochemists who were almost exclusively medical doctors. Perhaps in those times the new ground to cover was so enormous that one did not bother about subdivisions. Perhaps, on the other hand, we tend to stick too much to our disciplines these days.

In the field of blood coagulation there is a very interesting personality that up to this moment did hardly get the attention he deserves: Cornelis A. Pekelharing (Fig. 1), a medical doctor who became professor of general pathology at the University of Utrecht, The Netherlands, in 1881 . In 1894 he described experiments that up to this day can be easily repeated and that demonstrate the existence of prothrombin. By repeated precipitations with $\mathrm{NaCl}$ and/or $\mathrm{MgSO}_{4}$ he obtained two fractions from normal plasma, neither of which clotted upon addition of $\mathrm{CaCl}_{2}$ and/or tissue thromboplastin. One of the preparations, however, after these additions acquired the capacity to make the other one clot. Pekelharing drew the correct conclusion: A proenzyme, prothrombin, is converted, under the influence of tissue thromboplastin and $\mathrm{CaCl}_{2}$, into an enzyme, thrombin that can make fibrinogen clot.

To my knowledge this does not only mark the discovery of prothrombin but also is the first demonstration of a proenzyme-enzyme conversion. It thus shows that the work of an M.D. on a medical problem often can yield results that are of seminal importance to biological sciences, to biochemistry in this case. It thus is a per- 


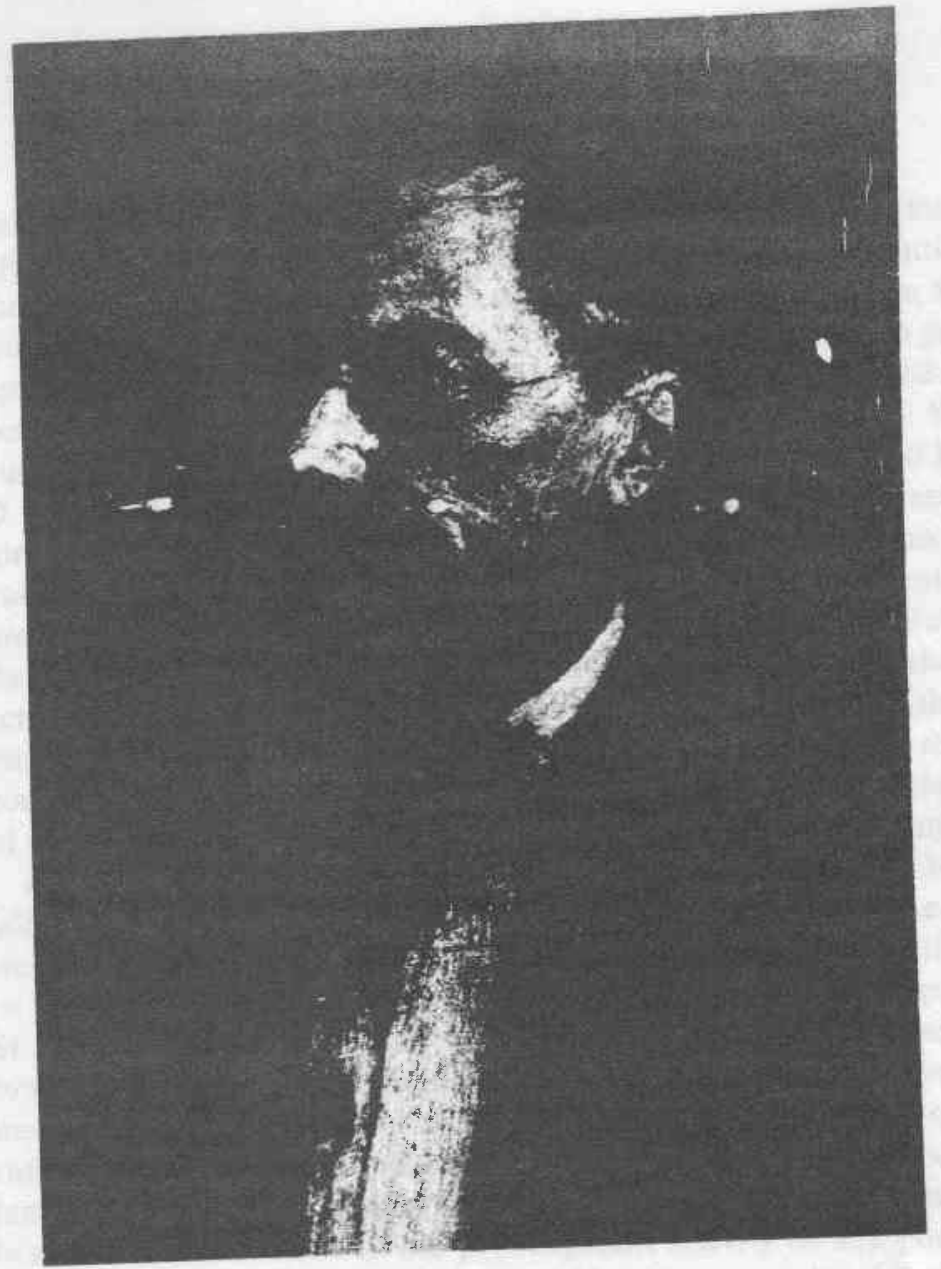

Fig. 1. Cornelis A. Pekelharing (1848-1922).

fect example of one of the main features of the interaction of medicine and chemistry: medical problems are a treasure trove for the biochemist who takes the pain to understand them correctly. Talking with a clinician and trying to understand his problems may be more difficult than running an ultracentrifuge or interpreting kinetic data but it may be at least as fruitful. The traffic between biochemists and medical doctors is often hampered by the failure of either one to try and understand the other's language. Now this can indeed be difficult. I have had the pleasure to work as a clinical assistant in the paediatric clinics of a pioneer of blood coagulation research: Prof. S. van Creveld. The astonishing ease with which he could suggest the most complicated biochemical research on the spur of a patient seen ('After this vacation we will attack von Willebrand's disease') was only rivalled by the astonishing answers that the scientists did indeed find under such 
guidance. I remind you of the discovery of platelet factor 3 (Paulssen) or the purification of factor VIII (van Mourik). On the other hand scientists tend to impose their way of thinking on their medical colleagues, more often focussing on problems that are likely to be solved than on those that will help to gain insight in pathophysiological mechanisms. Yet, up to this day, the liaisons and cross-fertilisations between scientists and practitioners remain many and varied. We see Prof. Magnusson, M.D., solve the primary structure of prothrombin and Prof. Duckert, Ph. D., solve many problems directly related to patient care. We see the medical doctors continuously improve on the quality of their clinical trials under the continuous criticism of the statisticians and we continue to find patients that help us pose problems of fundamental interest and solve them. It is only relatively recently that the Fletcher and Fleaujac deficiencies led to the discovery of the details of contact activation, that a study of the membrane proteins in congenital thrombopathies gave important clues to the receptor functions in platelets or that the problems of the control of oral anticoagulation inspired the experiments that led to the discovery of carboxyglutamic acid and the mechanism of action of vitamin $\mathrm{K}$.

A 'more than life size' example plays just at this moment (October 1984) in our laboratory while Mrs. Scott is visiting us. Mrs. Scott is an American lady who was treated by Dr. Weiss in New York for a mild thrombopathy that he could define to be a lack of platelet procoagulant activity. Later the group of Dr. Majerus in St. Louis also did experiments with her platelets and they concluded that a membrane protein receptor for the formation of prothrombinase was lacking. On the basis of quite different experiments our group arrived at the conclusion that it is rather the transbilayer lipid movement in platelets that causes platelet procoagulant activity. It makes phosphatidyl serine available at the outside of the membrane, which is crucial to the procoagulant activity of any phospholipid preparation. Now indeed if the platelets of Mrs. Scott can be shown to lack a protein receptor the 'American' view must be deemed right. On the other hand, if Mrs. Scott's platelets do not show phospholipid flip-flop, our concept of PF 3 is the more likely one. So at this moment we are determining whether only prothrombinaseforming capacity is lacking in her platelets or whether the capacity to support the formation of the factor X-converting enzyme is lacking as well. If this is the case, either the receptor is aspecific or two receptors are lacking at the same time. We will also see whether or not phosphatidyl serine will show up at the outside of her triggered platelets. In this way we hope to settle a difference in opinion in a way that will convince our American colleagues (cf. Rosing et al. (1985) Blood 65, 1557-1561).

This case is a perfect modern example of the continuous need, also in modern biochemistry, of 'the experiment of nature' that is to be found in the clinics. Also of the continuous need for biochemists alert for rare cases presented by clinicians and of the need for continuous attention from the side of the doctors, in order to find those cases that may help solve scientific problems. Alas it must be said that only a small part of the doctors burdened by an everyday practice have the talent and/or interest to pay attention to this part of medical science. And also that those 
who do. will often not find a scientist competent and willing to listen to their story and grasp its possible meaning. The fact that such contacts are rare makes one think that much valuable material slips constantly through the hands of the clinicians. This is readily illustrated by the fact that a relatively common disorder like congenital fibrinogen abnormality seems to cluster around places where good coagulation labs are to be found. One wonders how this can be remedied. Making clinical doctors responsible for the research lab, as it used to be done in the past and still is often seen nowadays is, in my opinion, not a good solution. Both tasks are so formidable that one of them - usually the fundamental research - tends to be neglected. Our solution has been to engage people with a clinical training in our research group. These doctors have a part-time function in the hospital and thus help establishing the bridge between the 'two cultures'. It may seem strange that we did not in the first place attempt a link via the routine coagulation lab. This however, was on purpose. More often than not the routine lab shields the clinics from the research department. Only in those cases where the latter is an integral part of the routine laboratory this can be avoided. If the head of the routine lab is not a research scientist with primary interest in the type of problems discussed in this article, the routine lab will not make the necessary 'traits d'union'. The clinician thinks that he has done his duty in sending his samples to 'the lab'. The clinical lab has its duty done if it applies routine tests to these samples and discusses the results with the clinicians and the research interests are nowhere to be seen. If on the contrary the routine lab joins in an existing dialogue between researchers and clinicians their contribution as 'case hunters' may be of great use. I conclude that the interplay between clinics and basic science up to this day is of paramount importance in haemostasis and thrombosis research. We must confess that the difficulties that arise in establishing the necessary links are often of an organisational and psychological nature. Recognising this may be a first step to a solution.

In view of the special subject of this article it is hardly useful to publish a list of references. To the reader interested in the history of blood coagulation research an extensive bibliography of the literature up to around 1900 is available upon request. 